\title{
Level of Knowledge and Attitude Achievement of Vocational High School Students in Blended Learning Implementation in The New Normal Era
}

\author{
Olivia Laras Sati ${ }^{1}$, Thomas Sukardi ${ }^{2}$, Puteri Anggieta Cahyani ${ }^{3}$ \\ \{olivialarassati09@gmail.com ${ }^{1}$, thomas_sukardi@uny.ac.id ${ }^{2}$, anggieputri337@gmail.com ${ }^{3}$ \} \\ Affiliation, Yogyakarta State University ${ }^{1}$, Affiliation, Yogyakarta State University ${ }^{2}$, Affiliation, \\ Yogyakarta State University ${ }^{3}$
}

\begin{abstract}
This research aims to vaccinate the level of knowledge and attitude achievement of students of State VHS 2 Yogyakarta and VHS Muhammadiyah 3 Yogyakarta on the implementation of blended learning. The research method used mixed methods sequential explanatory, research samples 83 respondents and 6 interview informants. Data collection techniques in the form of tests, observations and interviews. The validity test was conducted by experts and tested to 30 respondents. Test questions in the form of multiple choice that refers to the syllabus, while the observation of attitude consists of eight aspects, namely discipline, responsibility, honesty, cooperation, creative thinking, courtesy, self-reliant and confident. The results showed that the level of student knowledge achievement in the implementation of blended learning by $77 \%$ of the category is quite good and the achievement rate of student attitude in the implementation of blended learning by $83 \%$ of the category is very good.
\end{abstract}

Keywords: Knowledge, attitude, blended learning, new normal

\section{Introduction}

Indonesian education is faced with many challenges and opportunities to adjust to the demands and dynamics of changes that will and are taking place. The 21 st century demands quality human resources and is able to be globally competitive. Indonesian education must always prepare the skills needed to face every 21 st century education revolution [1], [2]. XXI century or technology century requires many konwledge workers with various basic skills as follows: (1) critical thinking and problem solving, (2) innovation and improvement, (3) flexibility and adaptablity, (4) leadership and initiative, (5) productivity and accountability, and (6) research and learning skills [3]. The rapid development of innovation and technology encourages education in various countries to analyze and find the type of learning that suits the demands of the 21 st century.

Effective Vocational Education should take into account the formation of student competence and its application. According to Catts, Falk, \& Wallace(2011, p. 7)"We contend that effective vocational learning comprises two equally important dimensions: (a) learning as the acquisition of vocational knowledge and (b) learning as the contextualized (socio-polytical and cultural) application of that know-ledge[4]". Revitalization of Vocational high school (VHS) No. 9 of 2016 in order to improve the quality and competitiveness of Indonesian human resources. The challenges of the global and industrial era 4.0 make all stakeholders of 
DUDI must be involved. However, based on the data listed in the Central Statistics Agency (BPS) shows the open unemployment rate of vocational schools is still the highest among other education levels, which is $8.49 \%$. Currently the world is facing the Corona Virus Disease 2019 pandemic.

The COVID-19 pandemic requires working, studying, and worshipping from home. COVID-19 is a virus that attacks the respiratory system [5]. This pandemic period resulted in a change in especially the implementation [6] and education in parts of the world is experiencing a crisis $33.1 \%$ of the world's student population is affected by school closures resulting in 579 million students dropping out of school and 35 countries affected by school closures [7]. However, since the beginning of June 2020, the Government has directed to enter a new life order during the COVID-19 outbreak, namely New Normal [8]. The ideal learning model in the middle of the pandemic according to Minister of Education Nadiem Makarim is Blended Learning. Blended Learning is a learning that combines the application of traditional learning in the classroom with online learning that utilizes information technology and is flexible, salain that the use of e-learning or online learning is one form of flexible learning examples in the Blended Learning method [9]. This model can improve participants' professional knowledge and the efficacy of personal teaching related to creativity instruction [10].

The blended learning type consists of synchronous and synchronous types. Blended learning types are out of sync, learning is done with the occasional teaching presence and combined electronic communication. There are no provisions for face-to-face learning or elearning. Meanwhile, in blended learning type synchronous learning provisions are 50/50 meaning $50 \%$ offline and $50 \%$ done online, or $75 / 25$ means $75 \%$ offline learning and $25 \%$ online, and can be done 25/75 means $25 \%$ offline and $75 \%$ online [11]. Blended learning has three different combinations: a combination of different media, combining different teaching methods and strategies, and a combination of face-to-face and online learning [12] with the implementation of blended learning is expected that students can understand the material better and be more active in following the learning, so as to improve student learning outcomes. Blended learning has three approaches used in the blended learning process including: face-to-face (formal), face-to-face (informal), virtual synchronous, virtual asynchronous, self-learning, and performance support. The various approaches of Blended learning such as behaviorism, constructivism, kognitivism with the aim to produce an optimal learning achievement with or without learning technology.

Competency knowledge aims to adjust the latest education, i.e. nouns turn into verbs. Knowledge competencies include cognitive spheres including: remembering, understanding, applying, analysing, evaluating, and creating [13]. Cognitive levels are described as follows.

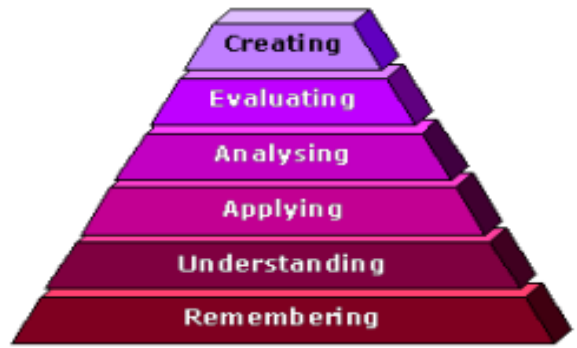

Fig. 1. Cognitive Domain

Source: Atherton (2013) 
Cognitive thinking ability is further studied that thinking activities are distinguished into 2 namely: Lower Order Thinking / LOT and Higher Order Thinking / HOT. The related cognitive realms of remembering, understanding and applying to Bloom taxonomy are part of LOT, while analyzing, evaluating and creating are part of HOT [14]. Aspects of knowledge on competencies for precision machining certification schemes include: 1) knowing work safety procedures, 2) knowing the requirements of procedures and product quality in meeting the required specifications, 3) knowing the working principles and how to use measuring instruments and their maintenance, 4) knowing how to read the images on the picture 5) understand the mathematical calculation formulas required in precision machining, e.g. on the determination of cutting parameters, 6) know the function of cutting tools according to their type, 7) know the working principles and operating procedures of tooling machines (lathes, frais, grinding and $\mathrm{CNC}$ ), and 8) know the order of work so that the machining process runs effectively, efficiently and safely [15].

The affective realm of bloom taxonomy consists of: receiving, responding, appreciating, organizing, and characterizing according to value [16]. The affective level is described as follows.

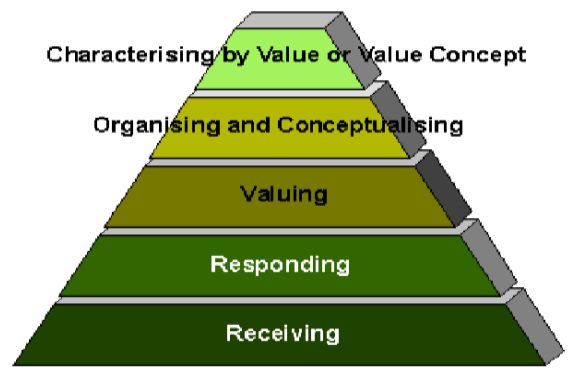

Fig. 2. Affective Domain

Source: Atherton (2013)

Aspects of attitudes to competence for precision machining certification schemes include: a. Comply with work safety procedures against self, tools/machinery and workpieces, b. Comply with quality procedures during the preparation, implementation and post-machining process, c. Careful in reading working pictures, d. Be thorough in using measuring instruments and measuring scales on machine eretan, and e. Be careful and careful in using hand equipment in accordance with its functions [15].

Regulation of the Minister of Culture and Education No. 66 of 2013 describes the techniques and instruments used for knowledge competency assessment: a. The writing test instrument is a question of multiple choice, stuffing, short answers, right-wrong, matchmaking, and description. with scoring guidelines, b. Oral test instruments are a list of questions. c. Instrument assignment in the form of homework and/or projects carried out individually or in groups in accordance with the characteristics of the task. While the technique of assessment of attitude competency include: a. Direct or indirect observation, using the reference observation, b. Self-assessment, with techniques to assess or expose from the less, c. Media with related requests and assessments, with which it is achieved and which are used to assess, d. Jurnal is an educator's record that contains observational information related to attitudes and behaviors.

Based on the results of a survey conducted by the Organisation for Economic Cooperation and Development (OECD) in 2015 using the Programme for International Student Assessment (PISA) test that the thinking ability of Indonesian learners is in the low category of level 2 
[17]. The statement was also supported by the Deputy Minister of Education and Culture that the quality of interpretation, exploration, and material proficiency of Indonesian students in the lower level. Another statement that the literacy ability of Indonesian students ranks below that of other countries [18].

In the industrialized world employers are increasingly complaining about the number of graduates who can not be faced with new challenges in the world of work, because of the large number of graduates lacking mastery of knowledge and skills [19]. Vocational Education graduates have not been able to adjust to the changes and developments in science and technology. Learners need superior skills and mastery of knowledge and attitude to get a decent job [20].

To be able to work well in the industry, especially the machining industry that uses advanced machines over time, namely optimization using $\mathrm{CNC}$ machines, the need for mastery of CNC competencies (Computer Numerical Control).

The capabilities of CNC machines are very complex and able to make a part or workpiece quickly and even complex workpieces can be made easily in large quantities. The demands of consumers who want the quality of workpieces that are precise, equally good quality, in a short time and in large quantities, will be easier to work with $\mathrm{CNC}$ machines. CNC machines are machines that can work through programming done and controlled through a computer. CNC machines can work automatically or semiautomatically after being programmed first through an existing computer.

The programming function in $\mathrm{CNC}$ is to create workpieces that have been planned or predesigned. Before the workpiece is executed by a CNC machine, the program must be checked in advance so that the program is completely in accordance with the desired form of workpiece, as well as completely workable by the CNC machine.

Students should at the time of learning is expected to focus on listening to the delivery of materials from educators and leave other activities that interfere with concentration during learning. Students are required to be active, creative, innovative so that at the time of graduation the school obtains knowledge and skills that should be in accordance with the SKL, in order to be applied in the world of work.

Based on previous research, several studies have been conducted related to the implementation of blended learning [21]-[25] Blended Learning is used to improve critical thinking skills, increase motivation and level of understanding of learners, logical thinking, mastery of concepts, learning activities and learning outcomes [26]-[29]. The quality of learning of learners, one of which can be achieved if applying the right learning model. But there are also students unable to adjust to new learning methods. Children who are at the education level are particularly vulnerable in case of not getting the same study material [30]. Therefore, in this study, the author wants to analyze the level of knowledge and attitudes of students in Class XII Machining Engineering Subjects NC/CNC and CAM State VHS 2 Yogyakarta and VHS Muhammadiyah 3 Yogyakarta which have implemented blended learning

\section{Research Method}

\subsection{Types of Research}

The type of research used mixed method sequential explanatory model. Sequential explanatory model of the first order with quantitative method, and second order qualitative 
method. This model is characterized by data collection and data analysis in the first stage of quantitative and the second stage of qualitative data collection, so that the data will be clearer and complementary to strengthen the results of quantitative research [31].

This study uses descriptive research types. Descriptive research is research that describes phenomena happening in real, realistic, actual because this research to make descriptive, picture or painting factually, systematically, accurately about the facts, properties and relationships between phenomena investigated [32]. This type of research does not hold manipulations or changes from the actual [33].

\subsection{Research Location and Time}

The research site was conducted at State VHS 2 Yogyakarta and VHS Muhammadiyah 3 Yogyakarta. The event was held in November 2020- January 2021.

\subsection{Population Research}

Population is the overall target that should be studied, and in that population the results of the study will be applied but if the population is too wide, then researchers must take a sample (part of the population) [34]. The population in this study is Class XII Learners of Machining Engineering Skills Competency.

Table 1. Blended Learning Approach

\begin{tabular}{|c|c|c|c|c|}
\hline No & School & $\begin{array}{c}\text { Skills } \\
\text { Program }\end{array}$ & $\begin{array}{c}\text { Competency } \\
\text { Skills }\end{array}$ & Respondents \\
\hline 1 & State VHS Yogyakarta & $\begin{array}{l}\text { Mechanical } \\
\text { Engineering }\end{array}$ & $\begin{array}{l}\text { Machining } \\
\text { Techniques }\end{array}$ & 120 \\
\hline 2 & VHS 3 Yogyakarta & $\begin{array}{l}\text { Mechanical } \\
\text { Engineering }\end{array}$ & $\begin{array}{l}\text { Machining } \\
\text { Techniques }\end{array}$ & 39 \\
\hline & Population & & & 159 \\
\hline
\end{tabular}

\subsection{Research Samples}

Samples are part of the number and characteristics that the population has. The sample taken must represent [35].

\subsubsection{Quantitative Sampling Techniques}

Sampling techniques in this study probability sampling using simple random sampling. To determine the sample size is by slovin formula. Slovin formula is used as determining the minimum sample size (n) if known population size $(\mathrm{N})$ at the level of significance of $\alpha$. The significance level used is 0.10 with the formula as below:

$$
\mathrm{n}=\frac{N}{1+N \alpha^{2}}
$$

Table 2. Quantitative Sampling Techniques

\begin{tabular}{ccc}
\hline No & School & Respondents \\
\hline 1 & State VHS 2 Yogyakarta & 55 \\
2 & VHS Muhammadiyah 3 & 28 \\
\hline
\end{tabular}




Yogyakarta
Number of respondents $\quad 83$

\subsubsection{Qualitative Sampling Technique}

The sampling technique used was non-probability sampling with purposive sampling. Purposive sampling is a sampling technique of data sources with a certain balance [35], namely students who are considered capable in that field.

Table 3. Qualitative Research Sample

\begin{tabular}{ccc}
\hline No & School & Respondents \\
\hline 1 & State VHS 2 Yogyakarta & 3 \\
2 & VHS Muhammadiyah 3 & 3 \\
& $\begin{array}{c}\text { Yogyakarta } \\
\text { number of respondents }\end{array}$ & 6 \\
\hline
\end{tabular}

\subsection{Variable Operation}

The operational definition of the variable used in this study is an independent variable. Independent variables are variables that stand alone without comparison or linking with other variables. The independent variables in this study:

1. Knowledge $\left(\mathrm{X}_{1}\right)$

There are four aspects of competence related to intellectual learning outcomes, namely: understanding, applying, analyzing, and evaluating.

2. Attitude $\left(\mathrm{X}_{2}\right)$

Competence related to a person's attitudes and values. Aspects that include: discipline, responsibility, honest, cooperative, creative, polite, independent, and confident.

\subsection{Data collection technique}

Data collection techniques are data collection in terms of ways/methods/techniques to collect data [36]. Data collection techniques used include:

\subsubsection{Tes}

Data collection techniques with tests to evaluate the knowledge of Class XII students when learning NC/CNC and CAM Machining Techniques by implementing blended learning. The test scale uses the traditional Guttman scale, which is a scale that gets answers to questions right or wrong. The assessment of the multiple choice test is below:

\section{Table 4. Test Rating Scale}

\begin{tabular}{cc}
\hline Answer Category & Score Weight \\
\hline Right & 1 \\
Wrong & 0 \\
\hline
\end{tabular}

Below is the analysis syntax of the achievement of the test results. 
Table 5. Test Analysis Alternative Syntax

\begin{tabular}{ccc}
\hline Predicate Value Range & $\begin{array}{c}\text { Predicate Value } \\
\text { Range }\end{array}$ & Category \\
\hline $89-95$ & A & Very good \\
$82-88$ & B & Good \\
$75-81$ & C & Pretty good \\
$68-74$ & D & Not good \\
$\leq 67$ & E & Very Not Good \\
\hline
\end{tabular}

(Sourch: [37])

\subsubsection{Observation}

The type of observation used was non-participant, namely the researcher was not involved and only as an independent observer with structured observation techniques, namely engagement and observation design, used with a systematic design. The assessment technique for observation is the Likert scale. The alternative observation syntax is as follows:

Table 6. Alternative Syntax of Observational Analysis

\begin{tabular}{ccc}
\hline Skor & Value Range & Alternative Answer \\
\hline 4 & $>75-100$ & Very Good \\
3 & $>50-75$ & Good \\
2 & $>25-50$ & Not Good \\
1 & $0-25$ & Very Not Good \\
\hline
\end{tabular}

(Sourch: [37])

\subsubsection{Interview}

The interview used is an unstructured interview, this type of interview is often used in more in-depth research on respondents [35].

Table 7. Grid of Semistructured Interview Guidelines

Aspect Indicator
a. Information
1. Activities
2. Atmosphere
3. Implementing blended learning
b. Knowledge
4. Barriers
1. Types and functions of cutting tools on a CNC lathe
2. Simulation of CAM milling program
3. Work steps in making workpieces using a $\mathrm{CNC}$ milling machine
c. Attitude
1. Contribution to learning
2. Friends attitude

Number of Items 


\subsection{Validity Test}

Validity testing is carried out by experts in the field of Machining Engineering. After testing the construction from the experts, then the learning achievement test is testing content validity with instrument testing. The instrument was tested outside the sample to be studied. The number of samples used is 30 respondents. After being tabulated, it was continued to correlate the scores of instrument items using SPSS Version 23 software for windows. The following are the validity results obtained:

Table 8. Validity Test Results

\begin{tabular}{|c|c|c|c|c|}
\hline No & Validity Index & No. Question Points & Amount & Percentage \\
\hline 1 & $\begin{array}{l}\text { If the index value } 0.281 \\
\text { then the item is declared } \\
\text { valid }\end{array}$ & $\begin{array}{l}1,2,3,4,5,6,7,8,10, \\
11,12,13,14,15,16, \\
17,20,21,22,23,24, \\
26,27,28,29,30,31, \\
32,34,35,36,37,38, \\
40,41,42,45,47,48, \\
49\end{array}$ & 40 & $80 \%$ \\
\hline 2 & $\begin{array}{l}\text { If the index value < } \\
0.281 \text { then the item is } \\
\text { declared invalid }\end{array}$ & $\begin{array}{l}9,18,19,25,33,39,43 \\
44,46,50\end{array}$ & 10 & $20 \%$ \\
\hline
\end{tabular}

(Source: Data Analysis Results, 2021)

Based on the table above, it is known that the number of questions is 50 questions. After testing the respondents, 40 questions with a percentage of $80 \%$ were declared valid because the index results items 0.281 with a valid category.

\subsection{Reliability Test}

Testing the reliability of the instrument to determine the level of consistency of the test questions. The test is declared reliable if it has a high interpretation of $0.60-0.79$. Instrument reliability testing was carried out internally using the Spearman Brown (Split half) formula. Spearman Brown's formula is as follows:

$\mathrm{r}_{i}=\frac{2 r_{b}}{1+r_{b}}$

\section{Information:}

$\mathrm{r}_{i}:$ internal reliability of all instruments.

$\mathrm{r}_{b}$ : Product moment correlation between the first and second hemispheres [35].

Based on the results of the analysis of multiple choice items in the NC/CNC and CAM machining engineering subjects, it was found that 50 multiple-choice test items obtained a test reliability result of 0.71 . So it can be concluded that the reliability of the multiple choice test subjects of $\mathrm{NC} / \mathrm{CNC}$ and $\mathrm{CAM}$ machining techniques has a high interpretation because it is included in the test reliability of $0.60-0.79$. 


\subsection{Data analysis technique}

Data analysis techniques in quantitative research are activities after data from all respondents or other data sources are collected. Activities in data analysis are carried out in several stages, namely: analyzing the results of test instruments, continuing to analyze interviews and documentation, tabulating data, presenting data and performing calculations to answer problems [35]. The analytical technique used is descriptive statistics. Descriptive statistics that discuss ways of collecting, summarizing, presenting data so that information is obtained that is easier to understand [36]. Descriptive statistics (including mean, median, standard deviation, frequency, and range) were calculated for all demographic questions and variables [38].

\section{Results and Discussion}

Implementasi blended laerning pada Vocational High School of Mechanical Engineering harus adanya capaian terkait pengetahuan dan attitude peserta didik. Pengetahuan adalah modal intelektual yang dapat bermanfaat melalui perspektif manusia, struktural, dan relasi. Manfaat pengetahuan dalam perspektif manusia ialah pengetahuan yang mencakup keterampilan (keahlian seseorang dalam suatu bidang) dan sikap (tanggungjawab, visioner, kejujuran, disiplin, ulet, kooperatif, dan tidak mudah menyerah) [39]. Adapun aspek pokok yang difokuskan dalam pemetaan ini bahwa kompetensi sumber daya manusia mengacu pada aspek knowledge dan attitude. SDM tanpa knowledge tidak akan punya dasar ilmu bertindak dan SDM tanpa attitude tidak mampu berperilaku kerja sesuai etika.

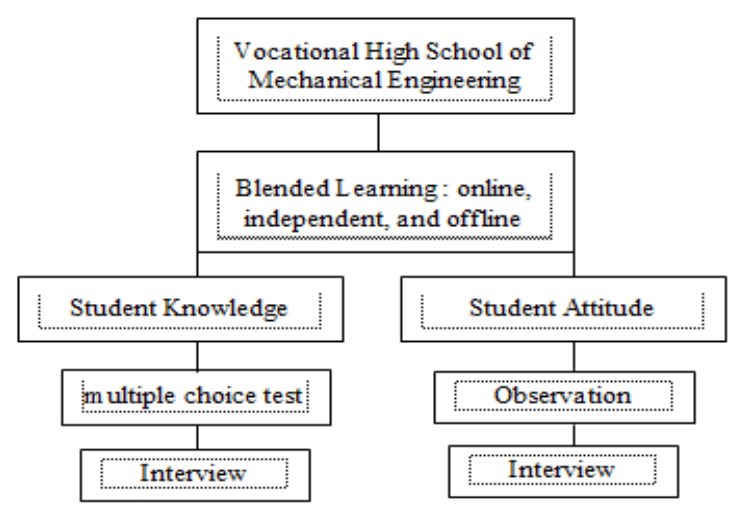

Fig. 3. Research Finding

\subsection{Knowledge}

Based on the results of knowledge research in both State VHS 2 Yogyakarta and VHS Muhammadyah 3 Yogyakarta, quantitative analysis shows that the level of knowledge achievement of students is quite good, seen from the percentage of knowledge test results as follows. 
Table 9. Knowledge Test Results of State VHS 2 Yogyakarta and VHS Muhammadiyah 3 Yogyakarta

\begin{tabular}{|c|c|c|c|c|}
\hline No & Aspect & $\begin{array}{c}\text { State VHS } \\
2 \\
\text { Yogyakarta } \\
\end{array}$ & $\begin{array}{c}\text { VHS } \\
\text { Muhammadiyah } \\
3 \text { Yogyakarta }\end{array}$ & $\begin{array}{l}\text { Mean } \\
(\%)\end{array}$ \\
\hline 1 & $\begin{array}{l}\text { Analyzing the CAM Milling program through a } \\
\text { simulation process }\end{array}$ & $77 \%$ & $75 \%$ & $76 \%$ \\
\hline 2 & Evaluating the G Code program & $85 \%$ & $79 \%$ & $82 \%$ \\
\hline 3 & $\begin{array}{l}\text { Understand the command function modify G } \\
\text { Code }\end{array}$ & $69 \%$ & $78 \%$ & $73 \%$ \\
\hline 4 & $\begin{array}{l}\text { Understand the transfer of G Code to CNC } \\
\text { Milling }\end{array}$ & $78 \%$ & $79 \%$ & $79 \%$ \\
\hline 5 & $\begin{array}{l}\text { Operate the program on the CNC Milling } \\
\text { machine }\end{array}$ & $78 \%$ & $75 \%$ & $76 \%$ \\
\hline 6 & $\begin{array}{l}\text { Understand Computer Aided Manufacturing } \\
\text { (CAM) for process Lathe }\end{array}$ & $75 \%$ & $75 \%$ & $75 \%$ \\
\hline 7 & $\begin{array}{l}\text { Understand the types of cutting tools and their } \\
\text { parameters for CNC Lathe }\end{array}$ & $87 \%$ & $79 \%$ & $83 \%$ \\
\hline 8 & Understand the command function for facing & $75 \%$ & $68 \%$ & $71 \%$ \\
\hline
\end{tabular}

(Source: Data Analysis Results, 2021)

Based on the table above, the level of knowledge achievement of students from both Vocational Schools is quite good in the basic competencies of understanding the transfer of $G$ Code to the CNC Milling machine, evaluating the G Code program, understanding the types of cutting tools and their parameters for CNC Lathe, analyzing the CAM Milling program through a simulation process, understanding transfer of G Code to the CNC Milling machine, as well as operating the program on the CNC Milling machine, while the basic competencies of students in understanding the command function to modify G Code and understanding the command function for the facing process are in the poor category. The following table shows the average percentage of VHS.

Table 10. Vocational High School Knowledge Achievement Level Results

\begin{tabular}{cccc}
\hline No & School & Mean $(\%)$ & Interpretation \\
\hline 1 & State VHS 2 Yogyakarta & 78 & Pretty good \\
2 & VHS Muhammadyah 3 Yogyakarta & 76 & Pretty good \\
& Amount & 154 & \\
& Average Percentage & 77 & Pretty good \\
\hline
\end{tabular}

(Source: Data Analysis Results, 2021) 
The table above states that the level of knowledge achievement of students with the test technique is $77 \%$ which is included in the pretty good interpretation. While the qualitative analysis with interviews stated that students of State VHS 2 Yogyakarta were able to answer questions well, seen from the explanation of the mention of the $\mathrm{G}$ code command function, program simulation and work steps in detail and precisely. Meanwhile, from VHS Muhammadiyah 3 Yogyakarta, the informants answered questions in a fairly good category because the answers explained were not detailed enough so that some were missed. There are several factors obtained by the researcher, namely according to the informant's statement that the teacher is not fully ready to implement blended learning seen from: first, the readiness of the lesson plans which still use the old format, which should use 1 sheet. RPP should also always be improved, namely in terms of form, content, and usefulness in meeting learning achievements. Second, the learning atmosphere is less interesting so that the topics to be delivered have not been able to build students' interest in learning, third, the time allocation has not fully improved the quality of learning, and fourthly the many obstacles from the network, web errors, unclear delivery, old teacher responses, and so on during online and offline learning. and also the lack of student interest in learning.

Aspects of knowledge (knowledge) based on competence include: 1) knowing occupational health and safety procedures, 2) knowing the requirements of procedures and product quality, 3) knowing the working principles and how to use measuring instruments and maintenance of measuring instruments and machines, 4) knowing how to read drawings 5) understand the mathematical calculation formulas needed in precision machining, 6) know the functions of the types of cutting tools, 7) know the principles and working procedures of CNC machines, and 8) know the work steps so that the machining process runs effectively, efficiently and safely [40].

\subsection{Attitude}

The results of the attitude achievement level of State VHS 2 Yogyakarta and VHS Muhammadiyah 3 Yogyakarta through quantitative observations are as follows:

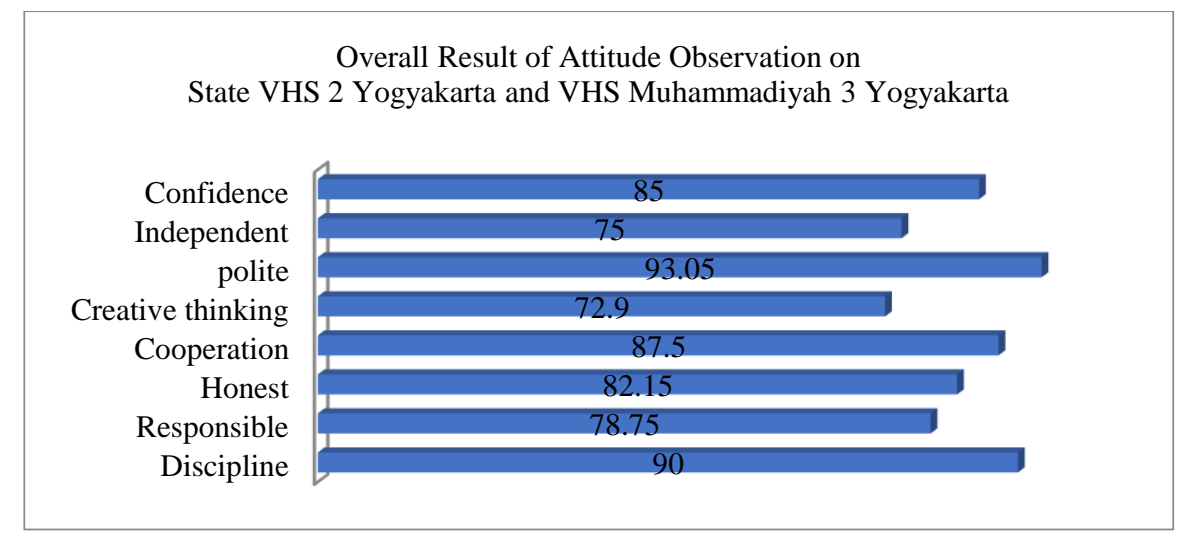

Fig. 4. Overall Results of Attitude Observations at State VHS 2 Yogyakarta and VHS Muhammadiyah 3 Yogyakarta

Judging from the percentage of observations, it can be concluded in accordance with the order of the highest aspect values with very good categories, namely polite attitude, discipline, 
cooperation, confidence, honesty, and responsibility. Meanwhile, the lowest aspects with good categories are (1) independent aspects, one of the objectives of implementing blended learning is so that students are able to learn independently [41] and, (2) creative thinking aspects, Creative thinking is an activity that generate new and innovative ideas. One of the indicators is the creation of new ideas that can solve problems and develop abilities [42] and (2) The following is a diagram of the results of observing student attitude achievements.

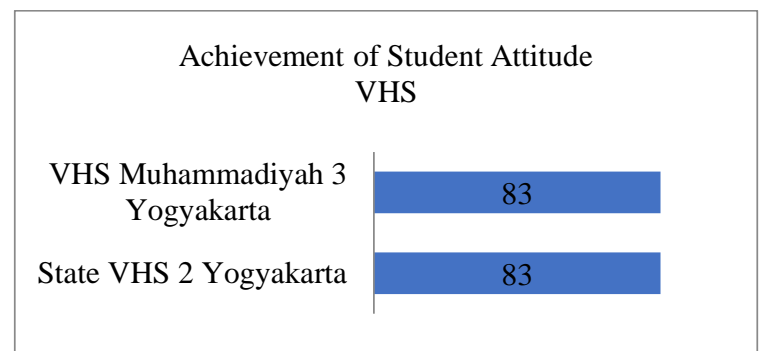

Fig. 5. Overall Results of Achievement of Attitude of Vocational Students

It can be seen from the diagram above that the highest achievement of students' attitudes at State VHS 2 Yogyakarta and VHS Muhammadiyah 3 Yogyakarta is the same, which is $83 \%$. The average achievement of the two schools is $83 \%$ in the very good category. Meanwhile, the attitude assessment between colleagues through interviews, stated that the attitudes of students with aspects of discipline, responsibility, cooperation and creativity were included in the good category. Based on the informant's statement that colleagues do assignments on time, maintain the cleanliness of the school environment, obey the rules of coming and going home from school according to the specified time, able to condition the class, dare to admit mistakes, dare to submit input or suggestions, and accept opinions from friends.

The 2013 curriculum requires teachers to conduct affective assessments. Affective assessment in the 2013 Curriculum is found in social attitudes, namely discipline, honesty, caring, self-confidence, courtesy and responsibility. It is important to do this regarding the affective assessment information of students with observation, so that teachers produce information that is biased in affective assessment. The social attitudes of students in the learning process can influence or improve student learning outcomes, and vice versa [43]. Purwanto (2011), says that attitudes always have a certain relationship with the object, the attitude is formed, studied or changed with respect to a certain object that can be formulated clearly [44].

Attitude has a motivational aspect and a feeling aspect, a natural trait that distinguishes people's attitudes, skills or knowledge. The positive attitude of students can be stimulated by interesting learning by providing innovations in media, methods, and assessments. A positive attitude that appears in students will provide good motivation, so students will excel. Attitude is an important aspect in life, especially in education, by having a positive attitude, it will make a person better in learning [45].

From the results of the two quantitative and qualitative data collection techniques, it was stated that the attitude level of the students of Vocational High Schools of Yogyakarta Province from the eight aspects, namely: discipline, responsibility, honesty, cooperation, creative thinking, polite, independent and confident was $82.4 \%$ very good category, and supported by qualitative results of assessment interviews between friends that students have good discipline, responsibility, cooperation and creativity. 


\section{Conclusion}

The conclusion of this research is: First, the level of knowledge achievement of students in the implementation of blended learning at State VHS 2 Yogyakarta is $78 \%$ good category and at VHS Muhammadiyah 3 Yogyakarta is 76\%. Overall, the level of knowledge achievement of students from the two VHS is $77 \%$ with a fairly good category. There are several factors causing the lack of maximum knowledge of students in the implementation of blended learning, namely: a. lack of teacher readiness in terms of lesson plans, time allocation, and learning atmosphere, b. the application of blended learning in CNC and CAM subjects increases the level of learning difficulties of students, $c$. there are obstacles during online and offline learning, as well as d. lack of interest in students to learn. Second, the level of achievement of students' attitudes on the implementation of blended learning at State VHS 2 Yogyakarta is $83 \%$ and at VHS Muhammadiyah 3 Yogyakarta is $83 \%$. Overall, the attitude achievement level of students of Vocational High Schools in Yogyakarta Province is 83\% with a very good category, and based on peer assessments that students do assignments according to deadlines, maintain the cleanliness of the school environment, obey school rules, come and go to school on time, able to condition the class, dare to admit mistakes, dare to give input or advice and receive opinions.

Acknowledgments. The researcher would like to thank colleagues who have helped in completing this article, and the researcher would like to thank the UMP for being willing to accept this article to be published in the EAI CCER Indexed in Scopus proceedings.

\section{References}

[1] S. PH, "POLITIK PENDIDIKAN INDONESIA DALAM ABAD KE-21," J. Cakrawala Pendidik., vol. 3, no. 3, p. 86218, Oct. 2014, doi: 10.21831/cp.v3i3.2377.

[2] E. Sulistiwati, Implementasi Kurikulum Pendidikan Karakter. Yogyakarta: PT Aji Citra Parama, 2012.

[3] Zamroni, Percikan Pemikiran Pendidikan Muhammadiyah. Yogyakarta: Ombak., 2014.

[4] R. Catts, I. Falk, and R. Wallace, "Vocational Learning: Innovative Theory and Practice (Vol. 13). Springer Science \& Business Media.- Google Buku," 2011, 2011. https://books.google.co.id/books?hl=id\&lr=\&id=Qih4_eq_3JUC\&oi=fnd\&pg=PR8\&dq=++R.+ Wallace++++(Eds.),+Vocational++++learning+innovative+theory+and+practice(pp.+18).+New+York:+Springer.\&ots=cGPlAU9bkM\&sig=2-dpaSJ4pnRIdiWQcXPgYjnKfg\&redir_esc=y\#v=onepage \&q= (accessed Dec. 04, 2020).

[5] Ontario Ministry of Education, "21st Century Competencies: Towards defining 21 st Century Competencies for Ontario," 2016. www.ksbe.edu/_assets/spi/pdfs/21_ce\%0Antury_skills_full.pdf.

[6] S. Burgess and H. H. Sievertsen, "The impact of COVID-19 on education | VOX, CEPR Policy Portal," 2020. https://voxeu.org/article/impact-covid-19-education (accessed Dec. 04, 2020).

[7] UNESCO, "COVID1-19 Impact on Education," 2020.

[8] C. Indonesia, "New Normal Jawa Barat Mulai Diterapkan 1 Juni,” May 27, 2020. https://www.cnnindonesia.com/nasional/20200527165110-20-507372/new-normal-jawa-baratmulai-diterapkan-1-juni (accessed Dec. 04, 2020).

[9] I. Syarif, "Pengaruh model blended learning terhadap motivasi dan prestasi belajar siswa SMK," J. Pendidik. Vokasi, vol. 2, no. 2, pp. 234-249, 2013, doi: 10.21831/jpv.v2i2.1034.

[10] Y. C. Yeh, L. Y. Huang, and Y. L. Yeh, "Knowledge management in blended learning: Effects 
on professional development in creativity instruction," Comput. Educ., vol. 56, no. 1, pp. 146156, Jan. 2011, doi: 10.1016/j.compedu.2010.08.011.

[11] W. D. Dwiyogo, Pembelajaran Berbasis Blended Learning. Malang: PT Raja Grafindo Persada, 2017.

[12] J. S. Drysdale, C. R. Graham, K. J. Spring, and L. R. Halverson, “An analysis of research trends in dissertations and theses studying blended learning," Internet High. Educ., vol. 17, no. 1, pp. 90-100, Apr. 2013, doi: 10.1016/j.iheduc.2012.11.003.

[13] L. W. Anderson and D. R. Krathwohl, "A taxonomy for learning teaching and assessing: a revision of Bloom`s taxonomy of educational objetives | Lorin W. Anderson, David R.

Krathwohl | download," 2001. https://b-ok.cc/book/2956998/e669c2 (accessed Dec. 04, 2020).

[14] R. A. Sani, "Pembelajaran Berbasis HOTS Edisi Revisi: Higher Order Thinking Skills," 2019. https://books.google.co.id/books?hl=id\&lr=\&id=GrfrDwAAQBAJ\&oi=fnd\&pg=PR5\&dq=(San $\mathrm{i},+$ Ridwan+Abdullah:+2019).\&ots=kHwUHZ3yw1\&sig=HC9VM520xHI5CVQsq6kJscbr_54\& redir_esc=y\#v=onepage $\& \mathrm{q}=($ Sani\%2C Ridwan Abdullah\%3A 2019).\&f=false (accessed Jul. 12, 2021).

[15] "Skkni 2018 109," 2018. https://www.scribd.com/document/405115370/SKKNI-2018-109-pdf (accessed Jul. 12, 2021).

[16] M. Muslich, Authentic Assesment Penilaian Berbasis Kelas dan Kompetensi. Bandung: Refika Aditama, 2011.

[17] A. Gurria, "PISA 2015 Results in Focus," PISA in Focus, (67), 1., Dec. 2016. https://search.proquest.com/docview/1853270009?pq-origsite=gscholar\&fromopenview=true (accessed Dec. 04, 2020).

[18] OECD, "PISA 2012 Results: Students and Money Financial Literacy Skills for the 21st Century Volume VI. Paris: OECD Publishing," Paris: OECD, 2012.

[19] S. B. Shum and R. D. Crick, "Learning dispositions and transferable competencies: Pedagogy, modelling and learning analytics," ACM Int. Conf. Proceeding Ser., no. December 2014, pp. 92-101, 2012, doi: 10.1145/2330601.2330629.

[20] D. A. Sudjimat, Pengembangan Kecakapan Kemampukerjaan: Untuk Meningkatkan Kualitas SDM Unggul Abad XXI. Malang: UM Press, 2013.

[21] L. Caporarello and A. Iñesta, "Make blended learning happen: conditions for a successful change process in higher education institutions," EAI Endorsed Trans. e-Learning, vol. 3, no. 12, p. 151716, 2016, doi: 10.4108/eai.2-12-2016.151716.

[22] C. Ghiringhelli and A. Lazazzara, "Blended learning for developing effective virtual teams: a proposed intervention format," EAI Endorsed Trans. e-Learning, vol. 3, no. 12, p. 151718, 2016, doi: 10.4108/eai.2-12-2016.151718.

[23] J.-H. Im and J. Kim, "Use of Blended Learning for Effective Implementation of EnglishMedium Instruction in a Non-English Higher Education Context," Int. Educ. Stud., vol. 8, no. 11, p. 1, 2015, doi: 10.5539/ies.v8n11p1.

[24] L. Jeffrey, J. Milne, G. Suddaby, and A. Higgins, "Blended Learning: How Teachers Balance the Blend of Online and Classroom Components," J. Inf. Technol. Educ. Res., vol. 13, no. January, pp. 121-140, 2014, doi: 10.28945/1968.

[25] H. Lewi, A. Saniga, W. Smith, L. Stickells, and D. Constantinidis, "Bringing the Classroom into the World: Three Reflective Case Studies of Designing Mobile Technology to Support Blended Learning for the Built and Landscaped Environment," vol. 5, no. 1, 2017, doi: 10.5278/ojs.jpblhe.v0i0.1556.

[26] C. Alfi, S. Sumarmi, and A. Amirudin, "Pengaruh Pembelajaran Geografi Berbasis Masalah Dengan Blended Learning Terhadap Kemampuan Berpikir Kritis Siswa SMA,” J. Pendidik. Teor. Penelitian, dan Pengemb., vol. Vol. 1, no. 4, pp. 597-602, 2016, [Online]. Available: http://journal.um.ac.id/index.php/jptpp/article/view/6203.

[27] A. K. Amin, "Kajian Konseptual Model Pembelajaran Blended Learning berbasis Web untuk Meningkatkan Hasil Belajar dan Motivasi Belajar," J. Pendidik. Edutama, vol. 4, no. 2, 2017.

[28] S. Bibi and H. Jati, "Efektivitas model blended learning terhadap motivasi dan tingkat pemahaman mahasiswa mata kuliah algoritma dan pemrograman," J. Pendidik. Vokasi, vol. 5, 
no. 1, p. 74, 2015, doi: 10.21831/jpv.v5i1.6074.

[29] D. Murni, S. Romlah, and N. Hodijah, "PENERAPAN BLENDED LEARNING BERBASIS SCAFFOLDING UNTUK MENINGATKAN KEMAMPUAN BERPIKIR LOGIS DAN HASIL BELAJAR MAHASISWA PADA MATA KULIAH BIOLOGI UMUM," BIODIDAKTIKA J. Biol. DAN PEMBELAJARANNYA, vol. 11, no. 1, 2016, doi: 10.30870/BIODIDAKTIKA.V11I1.1578.

[30] L. V. Hignasari, "Impact Analysis of Online Learning Toward Character Education of Elementary School Students In The New Normal Era," New Norm. Idealism Implement. Indones. Philipp., pp. 225-244, 2020.

[31] Sugiyono, Metode Penelitian Kombinasi (Mixed Methods). Bandung: Alfabeta, 2012.

[32] A. Rukajat, "Pendekatan Penelitian Kuantitatif: Quantitative Research Approach - Ajat Rukajat - Google Buku," CV BUDI UTAMA, Oct. 2018.

https://books.google.co.id/books?hl=id\&lr=\&id=1pWEDwAAQBAJ\&oi=fnd\&pg=PP1\&dq=ku antitatif+deskriptif\&ots $=9 \mathrm{PhDzldPo} 2 \&$ sig $=7 \mathrm{bgOn} \_$Tofof 9 NdepjLeB6IKtqOY\&redir_esc $=\mathrm{y} \# \mathrm{v}$ $=$ onepage $\& \mathrm{q}=$ kuantitatif deskriptif $\& \mathrm{f}=$ false (accessed Dec. 08, 2020).

[33] A. S. E. B. Hamdi, Metode Penelitian Kuantitatif Aplikasi dalam Pendidikan. Yogyakarta: CV. Budi Utama., 2014.

[34] M. Abdullah, Metode Penelitian Kualitatif. Banjarmasin: Aswaja Pressindo, 2015.

[35] Sugiyono, Metode Penelitian Kuantitatif, Kualitatif, dan R\&D. Bandung: Alfabeta, 2015.

[36] Muchson, "Statistik Deskriptif," in Guepedia, Guepedia, 2017.

[37] Sugiyono, Metode Penelitian Pendidikan (Pendekatan Kuantitatif, kualitatif, dan R\&D), 23rd ed. Bandung: Alfabeta, 2016.

[38] J. Williams, "Vigorous Activity Usage of Self-Identified Leaders: A Descriptive Quantitative Analysis," Open J. Leadersh., vol. 09, no. 01, pp. 53-69, 2020, doi: 10.4236/oj1.2020.91004.

[39] S. Arbainah, J. Handayani, H. Utami, K. Pinandhito, J. Akuntansi, and J. Administrasi Bisnis, "MECHANISM OF MAPPING THE NEED FOR HUMAN RESOURCES DEVELOPMENT IN MICRO INDUSTRY."

[40] B. Pracihara, "Instruksi Presiden No 9 Tahun 2016 (Revitalisasi Smk) Memacu Smk Bidang Seni dan Industri Kreatif dalam Pengembangan Ekonomi Kreatif," pp. 313-319, Oct. 2017, Accessed: Dec. 04, 2020. [Online]. Available: https://indrifatmawati389.

[41] E. Oktarina, S. D., Budiningsih, A., \& Risdianto, "Model Blended Learning Berbasis Moodle.," Jakarta Barat Moeka Publ., 2018, doi: doi.org/Moeka Publishing.

[42] G. Kolcu, S. Demir, K. Gülle, T. Atay, M. İ. B. Kolcu, and A. Koşar, "Evaluation of Transition to Distance Education in COVID-19 Pandemic," Res. Sq., pp. 1-9, 2020, doi: 10.21203/rs.3.rs35396/v1.

[43] "ERIC - EJ1060855 - Attitude Towards Physics and Additional Mathematics Achievement Towards Physics Achievement, International Education Studies, 2015." https://eric.ed.gov/?id=EJ1060855 (accessed Jul. 12, 2021).

[44] M. Purwanto, Psikologi Pendidikan. Bandung: Remaja Rosdakarya, 2011.

[45] L. Anggraini and R. Perdana, "Hubungan Sikap dan Percaya Diri Siswa Pada Mata Pelajaran IPA di Sekolah Menengah Pertama," SPEKTRA J. Kaji. Pendidik. Sains, vol. 5, no. 2, p. 188, 2019, doi: 10.32699/spektra.v5i2.103. 